\title{
The Relevance of Intangible Cultural Heritage and Traditional Languages for the Tourism Experience: The Case of Ladin in South Tyrol
}

\author{
Serena Lonardi * and Yvonne Unterpertinger
}

Citation: Lonardi, S.; Unterpertinger,

Y. The Relevance of Intangible

Cultural Heritage and Traditional

Languages for the Tourism

Experience: The Case of Ladin in

South Tyrol. Sustainability 2022, 14,

2729. https://doi.org/10.3390/

su14052729

Academic Editors: Harald Pechlaner, Stefan Schneiderbauer, Paola

Fontanella Pisa and Felix

Windegger

Received: 22 December 2021

Accepted: 22 February 2022

Published: 25 February 2022

Publisher's Note: MDPI stays neutral with regard to jurisdictional claims in published maps and institutional affiliations.

Copyright: (c) 2022 by the authors. Licensee MDPI, Basel, Switzerland. This article is an open access article distributed under the terms and conditions of the Creative Commons Attribution (CC BY) license (https:// creativecommons.org/licenses/by/ $4.0 /)$.
Department of Strategic Management, Marketing and Tourism, University of Innsbruck, Universitätsstraße 15, 6020 Innsbruck, Austria; yvonne.unterpertinger@gmail.com

* Correspondence: serena.lonardi@uibk.ac.at

\begin{abstract}
Cultural tourists have become increasingly interested in intangible cultural heritage and in minority, peripheral areas. This paper will focus on the ICH of minority communities, with a closer look at minority languages, considering the Ladin communities of South Tyrol (Italy). This study uses a qualitative methodology-16 semi-structured interviews with German- and Italianspeaking tourists in Val Pusteria, with a video presenting a real-life situation in Ladin. It reveals that, although culture is not the main motivation to travel to South Tyrol, tourists are fascinated by tangible and intangible aspects of the South Tyrolean culture, such as the architecture, traditional lifestyle, events, practices, dresses, and the language. What is particularly interesting is the role that cultural sustainability plays for the region: the successful maintenance of traditions, including the traditional languages - dialect and Ladin-are mentioned with affection. Tourism practitioners in Val Pusteria and the neighboring Ladin valleys should consider experiences in and with the Ladin language as fun and interesting for tourists but should also provide interpretational and educational support.
\end{abstract}

Keywords: intangible cultural heritage; minority language; cultural tourism; cultural sustainability; sustainable tourism; Ladin language

\section{Introduction}

Even though culture remains the main reason for tourism consumption [1], recent years have seen some significant changes in the cultural tourism industry, i.e., increasing interest in intangible cultural heritage and in minority, peripheral areas [2,3]. According to Richards [4], cultural elements, including $\mathrm{ICH}$, contribute to the attractiveness and distinctiveness of the destination. ICH includes all practices, traditions, and knowledge that a community considers part of its cultural heritage, and includes, inter alia, oral traditions, and languages [5]. Similarly, many linguists, such as Heller [6], have seen the language as one of the elements that contribute to defining the cultural heritage of a population, since it is "best able to name the artifacts and to formulate or express the interests, values, and worldviews of that culture" [7] (p. 20). This explains the growing interest in minority languages by tourists [8-10].

In fact, research in the field of sociolinguistics of tourism has focused on the interest in languages and language learning prior to traveling [11,12]. Even though the most used language in tourism situations is English—being a lingua franca-some tourists perceive the acquisition of language of the destination as a souvenir [11], with the consequence of language commodification $[6,13]$. In some cases, the desire and need for tourists to learn the language of the country they are visiting has resulted in a niche market: language tourism [14].

However, the continuous growth of tourism and the consequences of the SARS- SARSCoV-2 pandemic call for a change in the paradigm and highlight the need for a sustainable 
development of cultural tourism [15]. Recently, scholars have debated the concept of cultural sustainability and whether it could be considered a pillar on its own or should be a sub-pillar of the social sustainability concept [16]. The preservation of ICH is particularly important for cultural sustainability since it is with constant practice that it survives and is transmitted to the next generation [17].

This study will focus on one aspect of ICH: minority languages. Even though some research into minority languages and tourism has been conducted before, Whitney-Squire [13] called for further research to focus on tourists' preferences. As languages are an essential part of the culture of a country/region $[7,18]$, it would be interesting to understand how tourists perceive this aspect.

This study focuses on South Tyrol, northern Italy, where the three official languages are German, Italian, and Ladin. The Ladin language is a Rhaeto-Romanic language spoken by approximately 30,000 people in two valleys of South Tyrol—ca. $4.5 \%$ of the population of the province [19]. Although Ladin is considered as definitely endangered by the UNESCO Atlas of the World's Languages in Danger [20], the language is particularly vivid in those valleys, with various initiatives to preserve and promote it [21].

Moreover, South Tyrol has been a well-known tourism destination for decades, especially appreciated because of the majestic mountains surrounding it. Pechlaner et al. [8] have shown that the Ladin culture also represents an added value for the tourists, who especially appreciate their customs, traditional clothing, architecture, and language. Through the qualitative analysis of 16 semi-structured interviews with tourists, this paper will contribute to the understanding of the relevance of cultural elements of the Ladin community-including the language-for the tourism experience in South Tyrol (Italy).

The following section will describe the theoretical framework behind the study, including three key themes: (1) cultural tourism, (2) intangible cultural heritage, (3) minority languages and tourism experiences. After that, the methodology, including the description of the case study, will be shown. The fourth paragraph will present the main results of this study, followed by the discussion. The final part of this paper will be dedicated to the conclusions of the study, with limitations and suggestions for further research.

\section{Theoretical Framework}

\subsection{Cultural Tourism}

Recent research in tourism studies has confirmed culture as the main motivation to travel [1,2]. The UNWTO General Assembly of 2017 has provided an updated definition of cultural tourism, highlighting that the industry has changed and is no longer entirely related to tangible monuments and sites. "Cultural tourism is a type of tourism activity in which the visitor's essential motivation is to [ ... ] experience [ ... ] the tangible and intangible cultural attractions [ ... ] in a tourism destination. These attractions [ ... ] relate to a set of distinctive [ ... ] features of a society that encompasses arts and architecture, historical and cultural heritage, culinary heritage, literature, music, creative industries, and the living cultures with their lifestyles, value systems, beliefs, and traditions." [22] (p. 30).

Richards [2], in his literature review, emphasizes various sub-themes that are emerging in the cultural tourism studies, such as cultural consumption, motivations for cultural tourism, economic aspects, the relationship between cultural heritage and tourism, and the creative economy. What is striking, according to Richards [2], is the rather interdisciplinary nature of cultural tourism studies.

Other studies have linked cultural tourism to visitors' engagement [23], satisfaction, and the intention to return to the holiday destination [24]. According to Richards [4], culture can be a driver of attractiveness for a tourism destination. In fact, the relationship between culture and tourism is mutual: on the one hand, tourism contributes to strengthening the competitiveness and distinctiveness of a place; on the other hand, tourism creates an income, which supports and valorizes culture [4]. In this model of culture, tourism, attractiveness, and competitiveness, governance plays a fundamental role through better public services, quality of life, as well as valorizing and preserving heritage [4]. Another fundamental 
study [25] highlights how local culture, as well as meaningfulness and involvement, are part of the seven domains that form part of a memorable tourism experience. According to Kim et al. [25], this domain consists of three aspects: "good impressions about the local people", "closely experienced the local culture", "local people in a destination were friendly" (p. 19).

What is particularly important for cultural tourism is the complex concept of authenticity [26], as cultural tourists search for "authentic" experiences of "everyday culture" [4]. MacCannell [27] first introduced the concept in tourism and leisure studies, with the use of the term "staged authenticity", i.e., when the local community creates and stages an appealing package for tourists. Wang [28] adds the concepts of "objective authenticity", i.e., "the authenticity of originals" (p. 352), where experts evaluate the genuineness and objectivity of an object, or event-and "existential authenticity" - i.e., when tourists are authentic to themselves.

Integrating tangible and intangible heritage in tourism and the increasing growth of cultural tourism has led to concerns about sustainable cultural tourism [2]. The notion of cultural sustainability has arisen in 1995, with the World Commission on Culture and Development, and focuses on the management and transmission of cultural heritage to the next generations [29].

Loulanski and Loulanski [30], for instance, provide a systematic analysis of the relationship between cultural heritage and tourism, and identify 15 critical factors for sustainable cultural tourism, including local involvement, education and training, authenticity, and interpretation, sustainability-centered tourism management, and integrated planning. Local involvement in tourism is especially fundamental for minority groups. For instance, community-based tourism [31,32] encourages the active participation of the community [4] in all phases of tourism development, especially tourism decision-making processes, because this reflects the interests of the community, which can profit out of tourism $[13,32,33]$. Finally, Soini and Birkeland [16] identify four aspects around which the concept of cultural sustainability is organized: heritage, vitality, economic viability, diversity, locality, eco-cultural resilience, and eco-cultural civilization.

In order to achieve cultural sustainability, education and learning are particularly important, since more educated tourists sometimes contribute to preserve and regenerate the cultural heritage [34]. Educational tourism, in fact, leads to a better awareness of both the local community and visitors [35]. Finally, educational experiences in the field of heritage tourism improve the memorability [36].

\subsection{Intangible Cultural Heritage}

The UNESCO Convention for the Safeguarding of the Intangible Cultural Heritage defines intangible heritage as "practices, representations, expressions, knowledge, skillsas well as the instruments, objects, artefacts and cultural spaces associated therewith-that communities, groups and, in some cases, individuals recognize as part of their cultural heritage" [5] (p. 5). According to the convention, ICH is manifested in various domains, such as oral traditions and languages, performing arts, rituals, practices, and traditional craftsmanship [5]. Because of their peculiar geographical positions, as well as historical and social reasons, mountain regions are often repository of ICH $[37,38]$.

One of the main changes in cultural tourism in the past few decades has been the increasing interest in living traditions [2]. Previous research has proven that tourists are interested in experiencing the authentic ways of life of the local population, including their ICH $[8,13,39]$. Moreover, including ICH in tourism experiences often allows for a certain amount of participation by tourists, who recommend these activities to their friends and relatives [40].

$\mathrm{ICH}$ is a particularly important aspect in the sustainable development of tourism because of its intangible and fragile nature, since it needs constant practice and recreation by the population to survive and be available for future generations $[5,17,29,41]$. In this vein, the concept of cultural sustainability gains particular importance [16]. Interestingly 
enough, previous studies have proven how the use of ICH in tourism activities has led to increased awareness of local cultural specificity [42]. Consequently, the interest of visitors has moved and motivated local community members to protect and promote their own culture. Furthermore, the locals have become visibly prouder of their cultural identity, including traditions and languages [42]. Another perspective sees ICH as a driver for sustainable tourism, as an asset that can contribute to fostering tourism during the off-season [43].

More recently, the UNWTO Inclusive Recovery Guide [41] highlighted the importance of sustainable and community-based tourism to strengthen the systems for transmitting $\mathrm{ICH}$ to future generations. UNWTO also recommends focusing on how ICH in tourism contributes to the improvement of the livelihoods of communities while it safeguards the social functions and cultural meanings of that heritage [41].

On the other hand, the tourism industry imposes changes in the living traditions and lifestyle of the local population, in order to make it relevant and marketable for the tourism market [44]. Particular importance must be therefore given to avoid over-commodification and exploitation of ICH by external actors [44-46].

\subsection{Minority Languages and Tourism Experiences}

As already mentioned, ICH also includes oral traditions and languages, as fundamental for the transmission of cultural heritage [5].

The traditional language in a tourist area is very present and guests are constantly in contact with it $[8,13,46]$. Whether in restaurants, shops, or alpine huts, tourists are constantly confronted with the traditional language of a place (see Figure 1 for an overview of touchpoints with the language). In fact, minority languages are even more specific and unique to a territory. The Council of Europe [47] defines minority languages as: "languages that are traditionally used within a given territory of a State by nationals of that State who form a group numerically smaller than the rest of the State's population; and [that are] different from the official language(s) of that State" (p. 2).

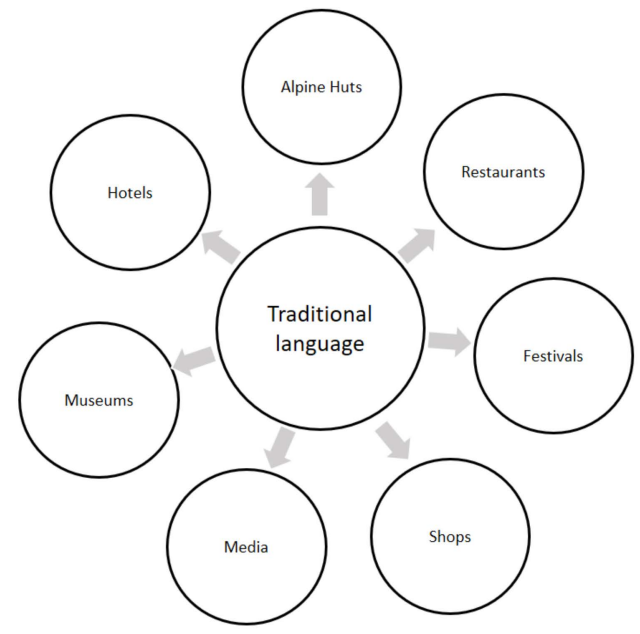

Figure 1. Touchpoints of culture and traditional language.

The potential of places with minorities for tourism is very high $[48,49]$. The sustainable use of their culture and languages can represent a competitive resource contribute to the variety and uniqueness of the destination's tourist offers and, thus, increase the engagement and memorability of the tourism experiences $[8,9,37,46]$. More specifically, languages can be also used as a guarantee of authenticity and, thus, serve as an asset for a holiday destination [46].

Previous research has proven that this kind of valorization of language leads to a revival, not only of the language itself but also of culture [48]. A growing interest from visitors from outside the community strengthened the cultural ties of the communities, by 
awakening a sense of pride in the individuals and an increasing desire to learn more about one's cultural heritage, including their traditional languages [37,42]. Moreover, cultural tourism can provide an alternative source of income in remote, rural areas, and contribute to sustaining traditions and local language $[17,48]$.

Of course, tourism can also have negative impacts on the minority languages because it can reinforce the hierarchies between the major and minor languages [50,51]. Furthermore, tourism can have a ripple effect that has a social impact on the cultural environment and can even destroy it if the local culture is exclusively used as a tourism attraction [33,52]. This can lead to increased social tensions and, in the worst case, cause a socio-cultural breakdown [53]. Bruyèl-Olmedo and Juan-Garau [51] also showed that in "beach and sand" tourism destinations_-such as Mallorca (Spain) — the minority language does not represent an added value and its presence in the public signs would not be welcomed by tourists.

Finally, the inclusion of minority languages in tourism experiences is, of course, full of complexities [54]. Minority languages are perceived as more authentic by tourists [45,55] and, thus, used to differentiate, and promote the destination and unique experiences $[8,13,37]$. Through educational experiences this can lead to preservation of those languages, thanks to higher income of touristic activities, increased sense of pride and identity, and desire to learn more about one's cultural heritage [13,48]. However, excessive commodification [6], stereotypization of minority languages, as well as increased use of global or national languages [50,51], aggravate, in some cases, language endangerment [50,51].

Building on previous knowledge about minority languages and tourism experiences, this paper will contribute to the understanding of tourists' motivations and preferences for tourism experiences involving a minority language, using a qualitative analysis of sixteen interviews with tourists, who frequently visit Val Pusteria (South Tyrol, Italy), considered an access point to the Ladin valleys.

\section{Materials and Methods}

\subsection{Case Study}

The study focuses on the autonomous province of Bozen/Bolzano or South Tyrol, which is an Alpine region located in the north of Italy, part of the region Trentino-Alto Adige. Tourism has been an important economic branch in the area for over 50 years and a significant source of employment [56-58], especially because of alpine summer and winter activities, as well as, more recently, food and wine tourism [58]. Table 1 provides an overview of the tourism industry in 2019 in South Tyrol. The year 2019 was chosen so that data would not be affected by the pandemic. South Tyrol, in 2019, was visited by 7.7 million people and mainly in the summer; the biggest share comes from Germany, followed by Italy. The most visited valley is Val Pusteria [59].

Table 1. Tourism in South Tyrol (data from tourism year 2018/2019) (ASTAT, 2020).

\begin{tabular}{lll}
\hline & Number & Percentages \\
\hline Arrivals & 7.7 million & \\
\hline Arrivals in summer & 4.7 million & $61.79 \%$ \\
\hline Arrivals German tourists & 3.4 million & $48.8 \%$ \\
\hline Arrivals Italian tourists & 2.6 million & $30.4 \%$ \\
\hline Arrivals in Val Pusteria & 2.2 million & $29.11 \%$ \\
\hline
\end{tabular}

It is important to highlight here that, in 2009, the Dolomites-a mountain range located in northeastern Italy-were declared a UNESCO World Heritage Site, because of the scientific importance of the geomorphology, geology, and the distinctive value of the mountain landscape.

South Tyrol is an interesting case study for this research: it is a trilingual regionItalian and German are the two most widespread languages, but in two valleys-Val 
Gardena and Alta Badia-most of the population speaks a minority language, the Ladin language. In fact, one of the assets of the region relies on the different cultural heritage and on numerous traditions.

The Ladin language is a Rhaeto-Romanic language, mainly spoken in the Dolomites (Italy) in the autonomous province of Bozen/Bolzano (South Tyrol, Italy), the autonomous province of Trento, and in the Veneto region, in the province of Belluno [19]. The language survived because of geographical, historic, political, cultural, and, of course, linguistic isolation from Italy and Tyrol $[19,21]$.

The language is nowadays still spoken by approximately 40,000 people in total-30,000 of which are in South Tyrol [19]. In Val Gardena and Alta Badia, in particular, most of the population can speak the language at a high level and use it daily: the language is officially recognized by provincial and national law, is present in trilingual street signs, is used in public administration, and is one of the teaching languages in schools and at the university. The Ladin Cultural Institute (Istitut Ladin Micurá de Rü), located in both Alta Badia and Val Gardena, is responsible for scientific studies of the language, history, and culture of the Ladin people, and for the maintenance of Ladin heritage, and through collaborations with schools. It is especially active in South Tyrol [19]. Therefore, in these two valleys, there is proof of an ample survival of this language, and people are very connected to this aspect of their heritage.

The Ladin language has always been part of the landscape and tourism experience in the two Ladin valleys of Val Gardena and Alta Badia, but also in Val Pusteria. Even though the tourism development in these destinations started with a focus on the nature, the mountains, and outdoor sports, more recently, the Ladin language and culture has become part of the tourism development [58]. Val Gardena and Alta Badia are keen to promote the Ladin culture and language, which is mentioned in brochures, websites, and social media, as well as in events that aim to inform visitors about their traditions, their rural lifestyle, and their language inside museums. The Museum Ladin Ćiastel de Tor, in Alta Badia, for instance, was inaugurated in 2001, whereas the Museum Ladin Ursus ladinicus was inaugurated in 2011.

These actions also contribute to the long-term preservation of the Ladin language and tradition [21]. The pride of a minority language group in their culture attracts tourists because this contributes to delivering authentic holiday experiences [27].

This research focuses on Val Pusteria as a case study, considered an access point to Val Gardena and Alta Badia, the two Ladin valleys in South Tyrol (see Figure 2). Val Pusteria is one of the most visited valleys in South Tyrol. It is known for its hiking paradises in the summer and great skiing experiences in the winter [59].

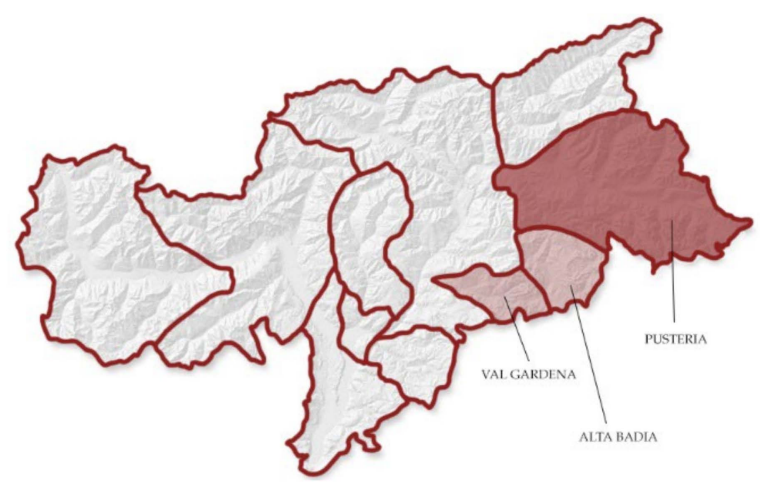

Figure 2. Map of South Tyrol.

\subsection{Methodology}

Since this is an explorative study, it will use a qualitative methodology; in particular, it will use semi-structured interviews with tourists. Semi-structured interviews allow for an in-depth understanding of the phenomenon being studied [60]. This method contains 
a set of prepared questions guided by overarching issues and themes, but it also allows asking follow-up questions or changing the order of the questions, if needed [61].

Two selected hotels in Brunico, Val Pusteria, were involved in the recruiting process of this study. Regular customers of one hotel were asked whether they wanted to participate in the study; these were then contacted via email by one author. Thus, interviewees were selected following the judgmental sample, which helped to gather rich information from a selected sample [62]; the main criterion was their repetitive visits, i.e., only tourists who had spent their holidays in Val Pusteria at least twice took part in the study.

Since visitors in South Tyrol are mainly from Germany, followed by Italy, the interview partners selected were 10 German-speaking and 6 Italian-speaking tourists, most of whom have been spending their holidays in South Tyrol since childhood-with a total of 16 interviews. Table 2 provides an overview of the interview partners according to their country of origin, age, and gender.

Table 2. Profile of the interview partners.

\begin{tabular}{llll}
\hline Interviewee & Origin & Age & Gender \\
\hline I1 & Germany & 24 & Male \\
\hline I2 & Germany & 62 & Male \\
\hline I3 & Germany & 45 & Female \\
\hline I4 & Germany & 60 & Male \\
\hline I5 & Germany & 21 & Female \\
\hline I6 & Germany & 56 & Male \\
\hline I7 & Germany & 55 & Female \\
\hline I8 & Germany & 23 & Female \\
\hline I9 & Italy & 53 & Female \\
\hline I10 & Italy & 58 & Male \\
\hline I11 & Germany & 56 & Female \\
\hline I12 & Germany & 58 & Male \\
\hline I13 & Italy & 52 & Female \\
\hline I14 & Italy & 24 & Male \\
\hline I15 & Italy & 57 & Male \\
\hline I16 & Italy & 56 & Female \\
\hline
\end{tabular}

The initial plan was to conduct the interviews face-to-face in the hotels selected [60]; however, due to travel restrictions caused by the pandemic, interviews were conducted online: thirteen interviews were conducted via Zoom and three interviews via WhatsApp video calls. With written permission from the interviewees, the interviews were audiorecorded for the subsequent analysis [60]. Interviews were held either in German or in Italian. Only significant quotes were translated into English.

The interviews were conducted over three weeks, from 22 February to 15 March 2021, and they lasted $31 \mathrm{~min}$ on average.

The interviews followed a set of prepared questions developed from previous literature $[8,13,54]$. The subjects were first asked about their memorable experiences related to the holiday spent in South Tyrol and in Val Pusteria. The aim was to find out what motivated them to choose this holiday destination, what they remember most, and what they valued most about this region [25]. The subjects were also asked about their experiences with the local culture and traditional languages [4]. In a third step, the interview specifically focused on the Ladin language: interviewees were put in a concrete situation of a possible experience in direct contact with this language. More specifically, a video in which a woman explains the preparation of a traditional dish in Ladin was shown. The last 
part of the interview was dedicated to opinions about the video and about similar tourism experiences $[8,25]$.

The data collected were analyzed with the data processing program MAXQDA through a combination of qualitative content [63] and thematic analysis [64]. The interviews were analyzed step-by-step by elaborating categories and subcategories and coding the data [63]. The two researchers conducted the thematic analysis separately, in order to improve the quality of data analysis, and then double-checked the analysis. After the individual coding, the two authors discussed it, reworded the categories and sub-categories and revised the analysis. To enhance the objectivity of the study, all different opinions were included in the analysis [65]. The analysis aimed to identify and report the patterns within the data by comparing codes and themes derived from the data [64].

\section{Results}

The findings of this study provide insights into the role of cultural heritage, especially the Ladin language, on the tourism experience of guests in Val Pusteria, South Tyrol (Italy).

\subsection{Travel Motivation and Memorable Experiences}

Results from the interviews reveal that the Alpine landscape and the atmosphere of the destination were the primary motivations to choose South Tyrol, and in particular Val Pusteria, as a holiday destination, and they represented the core values for tourists.

“... when we arrived there for the first time it seemed like paradise [ ... ] the landscape is breathtaking [ ... ] the first thing that amazes you is the beauty of this wonderful place..."

Some of the participants felt that the colors of the landscape were stronger and richer than in their hometowns:

"It's sunnier, to be sure. And greener. Even the meadow itself with the pinewoods [ ... ]. In short, there is [ ... ] always something more here. An extra gear."

Another interesting aspect that interviewees often mentioned was the contact with locals, which contributed to a feeling of home and of being welcomed. Experiences with locals, their friendliness, and hospitality were especially praised and perceived as a trademark for this valley.

"You always have the impression that you are welcomed in a friendly way [ ... ].

It gives you the impression of arriving and also a bit of home."

"The people. The people, the friendliness, the impression of being welcome. That's what always sticks with us and that's exactly why we come back."

Many interviewees took their holidays in Val Pusteria on an annual basis and they were balanced between summer and winter stays. It was very interesting to see that summer and winter visitors were fascinated by different things. Guests who spent their holidays in South Tyrol in the summer focused on the colors and smells that surrounded them. Winter visitors, on the other hand, were particularly concerned in the skiing area, weather, and snow conditions.

"We went to a mountain hut somewhere and everything there was decorated with flowers, so there were lots of colors and it looked so beautiful." 
"We mainly come in winter because Kronplatz is also a very beautiful skiing area. In my opinion, one of the most beautiful."

Moreover, the traditional food of the region was also often noted as a memorable experience. Many guests found South Tyrolean food to be a balanced mix between traditional and modern. Another very important point in the tourists' memorable experiences was represented by cultural traditions, such as festivals, food, events, and the language.

"You know when I even hear your voice, I think of [ . . . ] the mountains, the fresh air, and the apple fritters."

"[ ... ] that's exactly why we travel there. We like the traditions, the language, the people. We like everything."

Language and accent were related to other tangible and intangible cultural assets of Val Pusteria, such as mountains or food; they were mentioned by two interviewees as one of the reasons for returning visits.

\subsection{Cultural Awareness}

In regard to cultural awareness among guests in Val Pusteria, some interesting aspects emerged. Only two of the interviewees stated that they felt too little contact with the local culture to be able to say anything about it. The other interviewees primarily stated that the traditions of this holiday destination were of great importance to them. When talking about culture in South Tyrol, many interviewees enthusiastically mentioned traditions and ICH: they talked about food, transhumance, traditional dresses, and traditional events. For instance, guests enjoyed visiting the traditional farmers' and craftsmen markets that took place weekly in various villages during the summer. Other interviewees focused more on how important the history of the region was for them and revealed that they visited various places and museums related to the history of South Tyrol.

"I like when I see how lively and still present traditions are in Pustertal. For example, in summer, when we were there, we saw those fires on the top of the mountains. [ ... ] Was it Herz-Jesu-Feuer (Mountain fires lit around Midsummer and summer solstice to remember the pledge given to the Heart of Jesus in the 18th century, after the victory against Napoleon's army.)?"

Many interviewees also found other tangible aspects of culture fascinating, such as architecture and craftsmanship. Regarding architecture, the traditional ski huts and farms, as well as the mix with the "modern", were particularly charming.

Finally, interviews often focused on the importance of preserving traditions, highlighting the difference between the holiday destination and the place where they usually lived, where many traditions had disappeared.

"I also really like when I see how alive, how present the customs still are in your country."

"I have seen a lot of embroideries and I find this a wonderful thing because ... I find it very beautiful that even now, in 2021, there is still respect for these customs and these craft practices."

Interviewees, therefore, valued this attachment of South Tyrolean to their heritage and their efforts to preserve tangible and intangible aspects of their heritage and transmit 
it to future generations. Finally, visiting a destination that valued cultural preservation contributed to the perceived authenticity.

\subsection{Traditional Languages}

The final part of the interviews was dedicated to traditional languages. Some interviewees specifically stated that they valued the traditional languages very much. However, most of them referred to the German dialect spoken in South Tyrol. To put the interviewees in a possible real-life experience with the traditional Ladin language, a video was shown to them in which Ladin was spoken. Most interviewees said they had no negative feelings or attitudes towards this video and welcomed the possibility to participate in such an experience with enthusiasm:

"So, for me, it would be an interesting experience. The language seems very friendly and bright. So, also very appealing [ . . . ] so very soft."

However, all of them said that they could not understand much of it-four interviewees even confessed that they could not understand anything — and that they had preferred to have a translation or subtitles.

"Oh, that would be ... you really can't understand a word. Without the subtitles I would have been hopelessly lost."

About half of the interviewees said that they had contact with the Ladin language in South Tyrol before, even though some of them-especially the German-speaking interviewees - confused it with the Italian language. The main contact with the Ladin language was in the linguistic landscape (signs of the streets, bars, and shops). Other contacts took place in restaurants or public places, such as the cable car, by listening to conversations between waiters or locals.

All interviewees who had direct contact with the Ladin language found it to be very positive, while only one participant had very negative memories. The negative statement was justified by the fact that not understanding the language on holiday was considered a stress factor. It was a reason for the participant to prefer the case study-Val Pusteria-and not to choose the neighboring Ladin valleys of Val Gardena and Alta Badia as holiday destinations.

“But I can't do anything with Ladin itself. There is nothing at all that you can grasp. [ ... ] It was too stressful. [ ... ] when you are in such a particular valley ... spend the holiday there would not be an option for us."

However, even though not exclusively related to the Ladin language, interviewees felt particularly connected to the traditional languages of South Tyrol and associated it with the holiday destination:

"Yes, the languages are also associated with the holiday destination itself."

" ... the sound of the language gives me a holiday feeling and at the same time a homely feeling."

As already mentioned in the paragraph about cultural awareness, ten interviewees said that they considered the preservation of the traditional language and culture of a holiday destination to be particularly important, as exemplified in the following quotes:

"For me, it is really nice when old languages are still spoken nowadays, especially in South Tyrol, where the language sounds so soft." 
"I always think it's nice how the population still cultivates this language. [ ... ] For me, it simply has something to do with tradition and with the love of one's own country, to continue to preserve and maintain what the older generation has built up. That is the attachment to the country and the place."

"I find [it] really very beautiful and very essential because [ . . . ] we should never forget where we come from, $[\ldots]$ the things that our grandparents $[\ldots]$ passed down to us."

" ... I thought that was good because it's a tradition that should be preserved."

To summarize, experiences with the Ladin languages were perceived differently: whereas almost all interviewees would perceive a tourism experience involving the Ladin language as positive, one was rather skeptical, mainly because he neither spoke nor understand the Ladin language. However, the fact that traditions and languages have been preserved until the present day has been considered an important added value by tourists, since it contributes to perceived authenticity and, sometimes, it becomes one of the travel motivations.

\section{Discussion}

Previous literature in tourism studies has underlined the importance for holiday destinations to create memorable tourism experiences [24], comprising of seven domains [25], in order to ensure the return of the tourists. Results of this research reveal that the repetitive tourists interviewed had had many positive memorable tourism experiences of their holidays in South Tyrol, which were the reasons for positive word-of-mouth, loyalty, and continuous visits to the destination $[13,24]$. In Val Pusteria, these memorable tourism experiences were mainly hedonic and relaxing, relating to the landscape, weather, and snow conditions $[24,25]$.

Even though cultural heritage was not mentioned by any interviewees as the first motivation to travel to South Tyrol-contradicting the studies by Richards [2,3], results reveal that personal contact of the guests with local people [25], their attitudes, and their ways of life were perceived as very positive and memorable [31,32]. "Good impressions about the local people" and "local people in a destination were friendly" were, in fact, mentioned by Kim et al. [25] (p. 19) as important aspects of the domain local culture; similarly, guests having warm memories of the friendliness and hospitableness of South Tyrolean. This kind of relationship with the local population was very important to the guests interviewed because it contributed to feeling welcomed in the destination. This has thus contributed significantly to the loyalty of many visitors, i.e., their annual returns $[13,24]$.

However, interviewees often also mentioned other aspects of the local culture as part of their memorable tourism experiences in Val Pusteria [25], including local history [10], living traditions, and other aspects of ICH [13,17,24,41,48]. Although to different degrees, interviewees said that they were happy to "closely experience the local culture" [25] (p. 19) and participate in authentic holiday experiences $[8,13,27,39]$, guaranteed by the constant effort of South Tyrolean to preserve their cultural heritage [17]. Culture and, secondly, language preservation, were often mentioned as fundamental aspects of the tourism experiences in South Tyrol by most interviewees, as suggested by Kim et al. [17]. This result is particularly interesting because it highlights how cultural sustainability can become a pull factor and contribute to the differentiation, attractiveness, and competitiveness of a destination $[4,13]$. In this vein, the governance in the region [4], including the local tourism governance, should encourage and financially incentivize initiatives to preserve the Ladin culture and language, as well as promote it both internally towards the local community [5] and externally towards visitors [19]. As Richards [4] theorized, governance and local 
management contribute to the competitive advantage of the region, through enhanced quality of life, sustainability, and culture preservation.

Proposition 1. Cultural sustainability, especially preservation of ICH, is part of a memorable tourism experiences and it can contribute to travel motivation.

Similarly, the Ladin language was not considered the main motivation to travel to Val Pusteria. However, tourists showed quite an interest in it and were keen on participating in a tourism experience in direct contact with it $[8,46]$. This partially confirms the studies conducted by Whitney-Squire [13] and Kelly-Holmes and Pietikäinen [10] that proved how tourists are fascinated and attracted by the traditional language of a place, as an essential part of the culture. Moreover, it also confirms that minority groups and their ICH offer added value for tourists, since they offer the authentic cultural specificity that tourists are looking for $[8,42,46,48]$.

Proposition 2. Minority languages contribute to destination distinctiveness and authentic cultural specificity.

However, when put in a real situation of language use in a tourism experience, every individual reacted differently [25]. While some guests felt comfortable with the Ladin language $[10,45,48,49]$, others were, to different degrees, deterred by the language barrier and found the lack of translation, subtitles, or education as possible problems for such an experience. This result contradicts the findings by Heller et al. [45], who showed that the understanding of the language is not fundamental, as long as the tourist perceives that the language is authentic. Furthermore, minority languages could be perceived as stress factors in tourist destinations, where most visitors just want to relax or play sports [51].

Proposition 3. Experiences in a language unintelligible to tourists could be perceived as negative, if there is no education, interpretation, or translation provided.

\section{Conclusions}

This paper contributes to a better understanding of the value that a place's culture and language provides to tourists and it especially focused on the Ladin heritage of South Tyrol. Even though culture, in general, and the Ladin language, in particular, are not the main pull factors for Val Pusteria, for almost every interviewee, the preservation of cultural traditions, including language, is important $[4,13,17]$.

The results contained in this study show that visitors are also concerned about the preservation and conservation of traditions and language [33]. The reason for this is the delivery of authentic cultural experiences, as well as positive emotions associated with traditions in South Tyrol [25].

This study provides interesting practical implications for tourism practitioners in the area. First of all, they should be aware that the Ladin language in tourism experiences can be a factor for attractiveness, especially when focusing on its successful preservation $[13,17]$. However, it is important to consider the problem of unintelligibility, i.e., tourism practitioners should develop experiences where language is embedded, but not the main factor; in other words, those experiences should include educational parts [34-36], have a translation or an interpretation [30]. With the help of educational experiences, tourists' interests in the languages of the region could increase.

Another implication is the contribution of local people in the tourism experiences of the area $[21,31,32]$ (this is already part of the offer for tourism experiences in Alta Badia Valley; see, for instance their official website: https: / /www.altabadia.org/en/alta-badiaitalian-alps-dolomites.html, last retrieved on 15 December 2021).

This study is not without limitations. First of all, qualitative methodologies consider fewer cases and their analyses are, to a certain degree, subject to the researcher $[60,62,63]$. Moreover, this study considered only one valley in South Tyrol—Val Pusteria—that is not a 
Ladin valley. Finally, travel restrictions caused by the COVID-19 pandemic hindered the possibility of conducting face-to-face interviewees with tourists in loco.

Further research should specifically focus on cultural sustainability [17,30-32]: on the one hand, it is important to study the role for destination attractiveness in the Ladin valleys, Val Gardena and Val Badia, and in their surroundings. On the other hand, a detailed understanding of what cultural sustainability means to the community is also needed.

Finally, even though some interviewees mentioned that the experience with the language would be rather negative due to unintelligibility, there is still no understanding on how education $[34,36]$ would influence their tourism experiences. Interest in educational tourism experiences and how those influence tourists' interests in languages need further attention and research. As mentioned, education could improve preservation of heritage and, thus, cultural sustainability, as well as the memorability of tourism experiences.

Author Contributions: Conceptualization, S.L.; Data curation, Y.U.; Formal analysis, Y.U. and S.L.; Investigation, Y.U.; Methodology, Y.U. and S.L.; Supervision, S.L.; Writing-original draft, S.L. and Y.U.; Writing-review \& editing, S.L. All authors have read and agreed to the published version of the manuscript.

Funding: The author would like to thank the University of Innsbruck for supporting this open access publication. It was published with financial support from the Vice Rectorate for Research of the University of Innsbruck.

Institutional Review Board Statement: Not applicable.

Informed Consent Statement: Not applicable.

Data Availability Statement: Not applicable.

Acknowledgments: The author would like to thank the interview partners.

Conflicts of Interest: The author declares no conflict of interest.

\section{References}

1. UNWTO. Tourism and Culture Synergies; World Tourism Organization (UNWTO): Madrid, Spain, 2018.

2. Richards, G. Cultural tourism: A review of recent research and trends. J. Hosp. Tour. Manag. 2018, 36, 12-21. [CrossRef]

3. Richards, G. Rethinking Cultural Tourism; Edward Elgar Publishing: Cheltenham, UK, 2021.

4. Richards, G. Increasing the attractiveness of places through cultural resources. Tour. Cult. Commun. 2010, 10, 47-58. [CrossRef]

5. UNESCO. Basic Texts of the Convention for the Safeguarding of the Intangible Cultural Heritage; UNESCO: Paris, France, 2003.

6. Heller, M. Globalization, the new economy, and the commodification of language and identity. J. Socioling. 2003, 7, 473-492. [CrossRef]

7. Fishman, J.A. Reversing Language Shift: Theoretical and Empirical Foundations of Assistance to Threatened Languages; Multilingual Matters: Frankfurt, Germany, 1991.

8. Pechlaner, H.; Lange, S.; Raich, F. Enhancing tourism destinations through promoting the variety and uniqueness of attractions offered by minority populations: An exploratory study towards a new research field. Tour. Rev. 2011, 66, 54-64. [CrossRef]

9. Ugolini, M.; Costa, K. I cimbri come fattore di attrattiva turistica. Quad. Lingue E Lett. 2009, 34, 113-133.

10. Kelly-Holmes, H.; Pietikäinen, S. Commodifying Sámi culture in an indigenous tourism site. J. Socioling. 2014, 18, 518-538. [CrossRef]

11. Cohen, E.; Cooper, R.L. Language and tourism. Ann. Tour. Res. 1986, 13, 533-563. [CrossRef]

12. Phipps, A. Learning the Arts of Linguistic Survival; Channel View Publications: Bristol, UK, 2006.

13. Whitney-Squire, K. Sustaining local language relationships through indigenous community-based tourism initiatives. J. Sustain. Tour. 2016, 24, 1156-1176. [CrossRef]

14. Redondo-Carretero, M.; Camarero-Izquierdo, C.; Gutiérrez-Arranz, A.; Rodríguez-Pinto, J. Language tourism destinations: A case study of motivations, perceived value and tourists' expenditure. J. Cult. Econ. 2017, 41, 155-172. [CrossRef]

15. Gössling, S.; Scott, D.; Hall, C.M. Pandemics, tourism and global change: A rapid assessment of COVID-19. J. Sustain. Tour. 2020, 29, 1-20. [CrossRef]

16. Soini, K.; Birkeland, I. Exploring the scientific discourse on cultural sustainability. Geoforum 2014, 51, 213-223. [CrossRef]

17. Kim, S.; Whitford, M.; Arcodia, C. Development of intangible cultural heritage as a sustainable tourism resource: The intangible cultural heritage practitioners' perspectives. J. Herit. Tour. 2019, 14, 422-435. [CrossRef]

18. Bradley, D.; Bradley, M. Language Endangerment; Cambridge University Press: Cambridge, UK, 2019.

19. Casalicchio, J. Ladinia dolomitica. In Lo Spazio Comunicativo Dell'italia e Delle Varietà Italiane; Krefeld, T., Bauer, R., Eds.; Publisher: München, Germany, 2020. 
20. Moseley, C. (Ed.) Atlas of the World's Languages in Danger; UNESCO: Paris, France, 2010.

21. Iannàccaro, G.; Dell'Aquila, V.; Chiocchetti, N. 11 La tutela istituzionale del ladino. In Manuale di Linguistica Ladina; Videsott, P., Videsott, R., Casalicchio, J., Eds.; De Gruyter: Berlin, Germany, 2020; pp. 378-393.

22. UNWTO. Definitions Committee on Tourism and Competitiveness (CTC). 2017. Available online: https://www.e-unwto.org/ doi/epdf/10.18111/9789284420858 (accessed on 3 November 2021).

23. Bryce, D.; Curran, R.; O'Gorman, K.; Taheri, B. Visitors' engagement and authenticity: Japanese heritage consumption. Tour. Manag. 2015, 46,571-581. [CrossRef]

24. Chang, Y.-L.; Hou, H.-T.; Pan, C.-Y.; Sung, Y.-T.; Chang, K.-E. Apply an augmented reality in a mobile guidance to increase sense of place for heritage places. J. Educ. Technol. Soc. 2015, 18, 166-178.

25. Kim, J.-H.; Ritchie, B.; McCormick, B. Development of a scale to measure memorable tourism experiences. J. Travel Res. 2012, 51, 12-25. [CrossRef]

26. Chhabra, D.; Healy, R.; Sills, E. Staged authenticity and heritage tourism. Ann. Tour. Res. 2003, 30, 702-719. [CrossRef]

27. MacCannell, D. Staged authenticity: Arrangements of social space in tourist settings. Am. J. Sociol. 1973, 79, 589-603. [CrossRef]

28. Wang, N. Rethinking authenticity in tourism experience. Ann. Tour. Res. 1999, 26, 349-370. [CrossRef]

29. Throsby, D. 22 Cultural Sustainability; Edward Elgar Publishing: Zottery, UK, 2003; Volume 183.

30. Loulanski, T.; Loulanski, V. The sustainable integration of cultural heritage and tourism: A meta-study. J. Sustain. Tour. 2011, 19, 837-862. [CrossRef]

31. Dangi, T.B.; Jamal, T. An integrated approach to "sustainable community-based tourism". Sustainability 2016, 8, 475. [CrossRef]

32. Okazaki, E. A community-based tourism model: Its conception and use. J. Sustain. Tour. 2008, 16, 511-529. [CrossRef]

33. Butler, R.; Hinch, T. (Eds.) Tourism and Indigenous Peoples: Issues and Implications; Elsevier/Butterworth-Heinemann: Oxford, UK, 2007.

34. Ritchie, B.W. Managing Educational Tourism; Channel View Publications: Bristol, UK, 2003.

35. Colton, J.; Harris, S. Indigenous ecotourism's role in community development: The case of the Lennox Island First Nation. In Tourism and Indigenous Peoples. ISSUES and Implications; Routledge: London, UK, 2007; pp. 220-233.

36. Arnould, E.J.; Price, L.L. River magic: Extraordinary experience and the extended service encounter. J. Consum. Res. 1993, 20, 24-45. [CrossRef]

37. Lonardi, S.; Martini, U.; Hull, J.S. Minority languages as sustainable tourism resources: From Indigenous groups in British Columbia (Canada) to Cimbrian people in Giazza (Italy). Ann. Tour. Res. 2020, 83, 102859. [CrossRef]

38. Peters, M.; Siller, L.; Matzler, K. The resource-based and the market-based approaches to cultural tourism in alpine destinations. J. Sustain. Tour. 2011, 19, 877-893. [CrossRef]

39. López-Guzmán, T.; Santa-Cruz, F.G. Visitors' experiences with Intangible Cultural Heritage: A case study from Córdoba, Spain. J. Herit. Tour. 2017, 12, 410-415. [CrossRef]

40. Wu, T.-C.E.; Xie, P.F.; Tsai, M.-C. Perceptions of attractiveness for salt heritage tourism: A tourist perspective. Tour. Manag. 2015, 51, 201-209. [CrossRef]

41. WTO. UNWTO Inclusive Recovery Guide UNWTO Inclusive Recovery Guide. Sociocultural Impacts of COVID-19; Issue 2: Cultural Tourism; UNWTO: Madrid, Spain, 2021.

42. Greathouse-Amador, L.M. Tourism and Policy in Preserving Minority Languages and Culture: The Cuetzalan Experience. Rev. Policy Res. 2005, 22, 49-58. [CrossRef]

43. Giudici, E.; Melis, C.; Dessì, S.; Ramos, B.F.P.G. Is intangible cultural heritage able to promote sustainability in tourism? Int. J Qual. Serv. Sci. 2013, 1, 101-114. [CrossRef]

44. Cheer, J.M.; Reeves, K.J.; Laing, J.H. Tourism and traditional culture: Land diving in Vanuatu. Ann. Tour. Res. 2013, 43, 435-455. [CrossRef]

45. Heller, M.; Pujolar, J.; Duchêne, A. Linguistic commodification in tourism. J. Socioling. 2014, 18, 539-566. [CrossRef]

46. Moriarty, M. Contesting language ideologies in the linguistic landscape of an Irish tourist town. Int. J. Biling. 2014, 18, 464-477. [CrossRef]

47. Council of Europe. The European Charter for Regional or Minority Languages; Strasbourg: European Treaty Series-No. 148; Council of Europe: Strasbourg, Paris, 1992.

48. Kelly-Holmes, H.; Pietikäinen, S. Language: A Challenging Resource in a Museum of Sámi Culture. Scand. J. Hosp. Tour. 2016, 16, 24-41. [CrossRef]

49. Kelly-Holmes, H.; Pietikäinen, S.; Moriarty, M. Promoting tourism in linguistic minority spaces on the Web: A study of linguistic and visual resources on tourist websites for Dingle, Ireland and Inari, Finland. Tour. Cult. Commun. 2011, 11, 31-42. [CrossRef]

50. Amara, M. Arabisation, globalisation, and Hebraisation reflexes in shop names in the Palestinian Arab linguistic landscape in Israel. Lang. Intercult. Commun. 2019, 19, 272-288. [CrossRef]

51. Bruyèl-Olmedo, A.; Juan-Garau, M. Minority languages in the linguistic landscape of tourism: The case of Catalan in Mallorca. J. Multiling. Multicult. Dev. 2015, 36, 598-619. [CrossRef]

52. Greenwood, D.J. Culture by the pound: An anthropological perspective on tourism as cultural Commoditization. In Hosts and Guests; University of Pennsylvania Press: Philadelphia, PA, USA, 2012; pp. 169-186.

53. Dyer, P.; Aberdeen, L.; Schuler, S. Tourism impacts on an Australian indigenous community: A Djabugay case study. Tour. Manag. 2003, 24, 83-95. [CrossRef] 
54. Lonardi, S. Minority languages and tourism: A literature review. J. Herit. Tour. 2021, 1-15. [CrossRef]

55. Pietikäinen, S. Multilingual dynamics in Sámiland: Rhizomatic discourses on changing language. Int. J. Biling. 2015, 19, 206-225. [CrossRef]

56. Pechlaner, H.; Sauerwein, E. Strategy implementation in the Alpine tourism industry. Int. J. Contemp. Hosp. Manag. 2002, 14, 157-168. [CrossRef]

57. Kofler, I.; Marcher, A.; Volgger, M.; Pechlaner, H. The special characteristics of tourism innovation networks: The case of the Regional Innovation System in South Tyrol. J. Hosp. Tour. Manag. 2018, 37, 68-75. [CrossRef]

58. Sidali, K.L.; Huber, D.; Schamel, G. Long-term sustainable development of tourism in South Tyrol: An analysis of tourists' perception. Sustainability 2017, 9, 1791. [CrossRef]

59. ASTAT, Landesamt für Statistik. Tourismusstatistik. 2020. Available online: https://qlikview.services.siag.it/QvAJAXZfc/ opendoc_notool.htm?document=Turismo.qvw\&host=QVS\%40titan-a\&anonymous=true (accessed on 30 October 2021).

60. Jennings, G.R. 9 Interviewing: Techniques. In Tourism Research Methods. Integrating Theories with Practice; Ritchie, B.W., Burns, P., Palmer, C., Eds.; CIBA Publishing: Wallingford, UK, 2005.

61. Kvale, S.; Brinkmann, S. Interviews: Learning the Craft of Qualitative Research Interviewing; SAGE: Los Angeles, CA, USA, 2009.

62. Marshall, M.N. Sampling for qualitative research. Fam. Pract. 1996, 13, 522-526. [CrossRef] [PubMed]

63. Mayring, P. Qualitative Content Analysis: Theoretical Foundation, Basic Procedures and Software Solution; SSOAR: Klagenfurt, Austria, 2014.

64. Braun, V.; Clarke, V. Using thematic analysis in psychology. Qual. Res. Psychol. 2006, 3, 77-101. [CrossRef]

65. Madill, A.; Jordan, A.; Shirley, C. Objectivity and reliability in qualitative analysis: Realist, contextualist and radical constructionist epistemologies. Br. J. Psychol. 2000, 91, 1-20. [CrossRef] [PubMed] 